\title{
ADVERSE PHOTOTOXIC EFFECT OF ESSENTIAL PLANT OILS ON NIH 3T3 CELL LINE AFTER UV LIGHT EXPOSURE
}

\author{
Svatopluk Binder', Adéla Hanáková1, Kateřina Tománková1, Klára Pížová1, Robert Bajgar', Barbora Manišová1, \\ Kristina Kejlová2, Hana Bendová2, Dagmar Jírová2, Hana Kolářová1 \\ ${ }^{1}$ Department of Medical Biophysics, Institute of Molecular and Translational Medicine, Faculty of Medicine, Palacký University, Olomouc, Czech \\ Republic \\ ${ }^{2}$ National Institute of Public Health, Prague, Czech Republic
}

\section{SUMMARY}

Aim: Natural or artificial substances have become an inseparable part of our lives. It is questionable whether adequate testing has been performed in order to ensure these substances do not pose a serious health risk. The principal aim of our research was to clarify the potential risk of adding essential oils to food, beverages and cosmetic products.

Methods: The toxicity of substances frequently employed in cosmetics, aromatherapy and food industry (bergamot oil, Litsea cubeba oil, orange oil, citral) were investigated using cell line NIH3T3 (mouse fibroblasts) with/without UV irradiation. The MTT assay was used to estimate the cell viability. Reactive oxygen species (ROS) which are products of a number of natural cellular processes such as oxygen metabolism and inflammation were measured to determine the extent of cellular stress. DNA damage caused by strand breaks was examined by comet assay.

Results: MTT test determined EC50 values for all tested substances, varying from $0.0023 \% \mathrm{v} / \mathrm{v}$ for bergamot oil to $0.018 \% \mathrm{v} / \mathrm{v}$ for citral. ROS production measurement showed that UV radiation induces oxidative stress to the cell resulting in higher ROS production compared to the control and non-irradiated samples. Comet assay revealed that both groups (UV, without UV) exert irreversible DNA damage resulting in cell death.

Conclusion: Our findings suggest that even low concentrations (lower than $0.0464 \% \mathrm{v} / \mathrm{v}$ ) of orange oil can be considered as phototoxic (PIF value 8.2) while bergamot oil is probably phototoxic (PIF value 4.6). We also found significant changes in the cell viability, ROS production and DNA after the cells were exposed to tested chemicals. Even though these substances are widely used as antioxidants it should be noted that they present a risk factor and their use in cosmetic and food products should be minimized.

Key words: essential oils, UV light, NIH3T3 cell line, MTT test, reactive oxygen species, DNA damage

Address for correspondence: S. Binder, Department of Medical Biophysics, Institute of Molecular and Translational Medicine, Faculty of Medicine, Palacký University, 77515 Olomouc, Czech Republic. E-mail: svatopluk.binder@email.cz

http://dx.doi.org/10.21101/cejph.a4354

\section{INTRODUCTION}

Recently many chemicals, dietary supplements, pharmaceuticals and cosmetics are introduced to the consumer product market. An assessment of the potential phototoxic hazard is needed for substances which are recommended for use in personal products applied to the human skin exposed to sunlight. This assessment should be carried out prior to their commercial use to avoid health risk.

Four essential oils (bergamot, Litsea cubeba, orange and citral) frequently used in food industry as flavours, in everyday items such as cosmetics and household cleaning products, or in pharmaceuticals and aromatherapy were investigated in this study.

Bergamot oil (BO) is widely used as a flavouring agent in foods and beverages and in various cosmetic products (for its citrus scent) that may be applied to sun-exposed skin areas, although some components of bergamot oil (bergapten, citropten, bergamoten and other furocoumarins) may cause phototoxic effects (1). It is also used to treat skin conditions, such as psoriasis or vitiligo (when applied to the skin), or to treat anxiety or depression (when used in aromatherapy).

Litsea cubeba oil is an aromatic essential oil extracted from the fresh fruits of Litsea cubeba. It is used as a flavour enhancer in foods, cosmetics and cigarettes; as a raw material in the manufacture of citral, vitamins A, E, and K, ionone, methyl ionone, and perfumes; and as an antimicrobial agent and insecticide (2).

Orange oil is produced by cells inside the rind of orange fruit. It is extracted or steam distilled as a by-product of orange juice production. It is mostly composed of d-limonene (more than 90\%), and is therefore often used in place of pure d-limonene, which has to be further extracted from the oil by distillation (3). Limonene is known to cause mild skin irritation, as it dissolves protective skin oils (4). Although there is no evidence for carcinogenicity or genotoxicity in humans. Limonene has been observed to cause cancer in male rats, by reacting with $\alpha 2 \mathrm{u}$-globulin, which is not produced by female rats (5).

Citral is the primary component of the essential oil of lemongrass, constituting well over half the total oil content. Citral is 
one of the many chemicals giving lemongrass its strong lemony aroma, and it is also found in lemons and a number of other lemon-scented herbs.

All essential oils are toxic at very high doses, especially if taken orally. Many essential oils are inherently toxic at very low concentrations due to very toxic components. Interestingly, many essential oils which are considered to be non-toxic may have a toxic effect on people previously sensitised with a given essential oil (6).

The above mentioned essential oils were tested using cell line NIH3T3 (mouse fibroblasts) with/without UV irradiation (non-toxic dose $5 \mathrm{~J} \mathrm{~cm}^{-2}$ ). Progressive methods of molecular biology, based on fluorimetry and fluorescence, were employed for identification of early morphological and functional changes on cellular level. Fluorescence methods for the study of cell damage using fluorescence probes offer results for the evaluation of phototoxicity and cell viability of adherent cells.

UV light irradiation can result in formation of oxygen radicals which are capable to impair DNA, membrane and other cellular structures (7). Irradiation of human skin by direct sunlight might lead to the occurrence of photoallergy and phototoxicity. Photoallergic reactions are T-cell-mediated immunological reactions, while phototoxic reactions are non-immunological events inducing cell damage. Most substances eliciting photoallergic reactions also have a phototoxic potential (8). Photoactivated drugs may induce DNA damage of skin cells resulting in the increase of skin cancer incidence (9).

DNA damage can be studied by various methods, for example by comet assay or microscopic methods. The comet assay also called single-cell gel electrophoresis (SCGE) is a sensitive, simple and quantitative technique for the detection of DNA damage. The comet assay can be employed for the detection of damage such as single and double strand DNA breaks or DNA repair $(10,11)$.

\section{MATERIALS AND METHODS}

NIH3T3 (mouse fibroblast cells) were utilized as a biological material for the MTT viability/phototoxicity assay, reactive oxygen species measurement and comet assay. The chemicals used included Dulbecco's Modified Eagle Medium (DMEM) (Sigma Aldrich), phosphate buffered saline (PBS, pH 7.4 own preparation) 5-(and-6)-chloromethyl-2',7'-dichlorodihydrofluorescein diacetate (CM-H2DCFDA, Invitrogen Co., USA), 3-(4,5-dimethyl-2-thiazolyl)-2,5-diphenyl-2H-tetrazolium bromide (MTT, Sigma Aldrich), HMP agarose (Serva, Biotech, Czech Republic), LMP agarose (Qbiogene, Genetica, Czech Republic), Trypsin (Sigma Aldrich), fetal bovine serum (FBS, Sigma Aldrich), $\mathrm{NaCl}$ (Tamda, Czech Republic), EDTA (ethylenediaminetetraaceticacid, Lachema, Czech Republic), Tris (tris(hydroxymethyl) aminomethane, Sigma Aldrich), Triton X-100 (Serva), $\mathrm{NaOH}$ (Sigma Aldrich), SYBR Green (Invitrogen Co, USA), and dimethyl sulfoxide (DMSO, Sigma Aldrich).

The commercially available essential oils used in this study, namely bergamot oil (A), Litsea cubeba oil (B), orange oil (C), and citral (D) were supplied by local Czech (B, C, D) and German (D) manufacturers.

Measurements were carried out on multi-detection microplate reader Synergy HT and by means of a transmission microscope
Olympus IX81 with DSU unit (Olympus, Japan). We also used 96 well plates (P-Lab, Czech Republic) for cell lines cultivation, glass cover slip (P-lab, Czech Republic), electrophoretic tank (Bio-RAD, Czech Republic), centrifugal machine (Biotech, Czech Republic), UV light source bank of four Phillips tubes TL-D 18/08 (320-400 nm), UVA meter (Type No. 37, Dr. Hönle, Germany), and Phototox Version 2.0 software (ZEBET, Germany).

The UV light source, used in the ECVAM validation study on 3T3 NRU PT (SOL 500, Dr. Hönle, Germany), was a doped mercury-metal halide lamp simulating the spectral distribution of natural sunlight (emission spectrum in the range of 280-700 nm). A spectrum almost devoid of UVB $(<320 \mathrm{~nm})$ was achieved by filtering with a $50 \%$ transmission at the wavelength of $335 \mathrm{~nm}$ (Filter H1, Dr. Hönle, Germany).

Sample preparation and more detailed information on the methods used in this study were described in the previous studies $(12,13)$. The phototoxicity assessment was performed using 3 T3 Balb/c fibroblasts (L1, ECACC No. 86052701) according to the OECD Test Guideline 432 accepted by EU Member States in 2000 and by OECD Member States in $2004(14,15)$. In our experiment we chose MTT cell viability assay instead of Neutral Red Uptake assay.

\section{Photoxicity Classification}

For concentration-response analysis Phototox Version 2.0 software (obtained from ZEBET, Germany) was employed. A test substance is predicted as having a potential phototoxic hazard if the photoirritation factor (PIF), calculated as the ratio of toxicity for each substance with and without UV light, is higher than 5. Using the Phototox software, a second predictor of phototoxicity, the mean photo effect (MPE) was also calculated. The MPE is a statistical comparison of the dose-response curves obtained with and without UV and a test substance is predicted as phototoxic if MPE is higher than 0.1 (16). According to the OECD Test Guideline 432, a test substance with a PIF $>2$ and $<5$ or an MPE $>0.1$ and $<0.15$ is predicted as "probably phototoxic" (15).

\section{MTT Assay}

The cells were treated with the tested compounds for 1 hour. Afterwards, the half of the treated cells (+UV) was exposed to $\mathrm{UV}$ radiation ( 50 minutes, $5 \mathrm{~J} \mathrm{~cm}^{-2}$ ). Fresh DMEM was replaced and the cells were incubated for 24 hours at $37^{\circ} \mathrm{C}$ Celsius and $5 \% \mathrm{CO}_{2}$ atmosphere. Subsequently the cells were incubated for 4 hours with $0.5 \mathrm{mg} / \mathrm{ml}$ MTT dissolved in DMEM, and then the medium was discarded and replaced by $100 \mu 1$ of DMSO leading to formazan crystals dissolution. The absorbance of formazan coloured crystals is measured spectrophotometrically at $570 \mathrm{~nm}$ and cell viability is evaluated.

\section{Reactive Oxygen Species Measurement}

The cells were treated with the tested compounds for 1 hour. 2',7'-Dichlorodihydrofluorescein diacetate (DCFH2) was employed as a fluorescence probe for detecting Reactive Oxygen Species (ROS) production. DCFH2 oxidation as a result of interaction with ROS yields fluorescent 2', 7'-dichlorofluorescein (DCF). The sample cells were incubated with the $20 \mu \mathrm{M}$ working 
concentration for 20 minutes and the resulting fluorescence was measured.

\section{Comet Assay}

The DNA damage was studied by applying the comet assay. The cells were incubated with the tested substances for 1 hour. Subsequently, after 6 hours, the cells were collected and embedded in an agarose gel, then lysed by lysis buffer and immersed in an electrophoretic tank to undergo electrophoresis. DNA fragmentation is the result of an electrophoretic separation. The samples were rinsed and stained by SYBR Green and immediately visualized by fluorescence microscope. The degree of DNA damage was evaluated by Comet Score software (TriTek Corporation, USA).

The DNA damage of the treated cells is qualitatively presented by the amount of the unwound DNA fragments, which resembles a comet, having a distinct head and tail (11). The head consists of intact DNA, while the tail is created by broken fragments of DNA or relaxed chromatin. The amount of DNA damage is directly proportional to the amount of DNA liberated from the head (17). To assess DNA damage of the cells we used three different parameters, Olive Tail Moment, Tail Length "(the length of DNA fragments migration from the comet head)" and Percentage of DNA in Tail. The Percentage of DNa in tail is calculated as the ratio between the total intensity of the tail and the total intensity of the comet." Olive Tail Moment (OTM) is defined as the product of the tail length and the fraction of total DNA in the tail. Tail moment incorporates a measure of both the smallest detectable size of migrating DNA (reflected in the comet tail length) and the number of relaxed/broken pieces (represented by the intensity of DNA in the tail) (18).

This parameter is considered to be particularly useful in describing heterogeneity within a cell population, as OTM can pick up variations in DNA distribution within the tail. Any changes in the level of DNA damage will be reflected most accurately by OTM measurement. OTM is well correlated with the tail length and tail DNA in different groups. Tail Length is the distance of DNA migration from the body of the nuclear core and it is used to evaluate the extent of DNA damage.

\section{Statistical Analysis}

The results were processed using software SPSS v. 15 (SPSS Inc., Chicago, USA). The data are presented as mean \pm SD of three independent experiments. The statistical significance was determined by an analysis of variance with ANOVA post hoc tests Dunnet (comparison with a control). Statistical analysis of the comet assay results was performed using Fisher exact tests with Bonferroni correction. $\mathrm{P}<0.05$ was considered statistically significant.

\section{RESULTS}

The phototoxicity test in vitro showed differences in the cytotoxicity with/without UV irradiation of the tested samples. We selected concentration scale ranging from $0.0464 \%$ (volume/ volume; v/v) to $0.000215 \% \mathrm{v} / \mathrm{v}$ (Fig. 1). The half maximal effective concentration EC50 values (concentration of a drug that gives
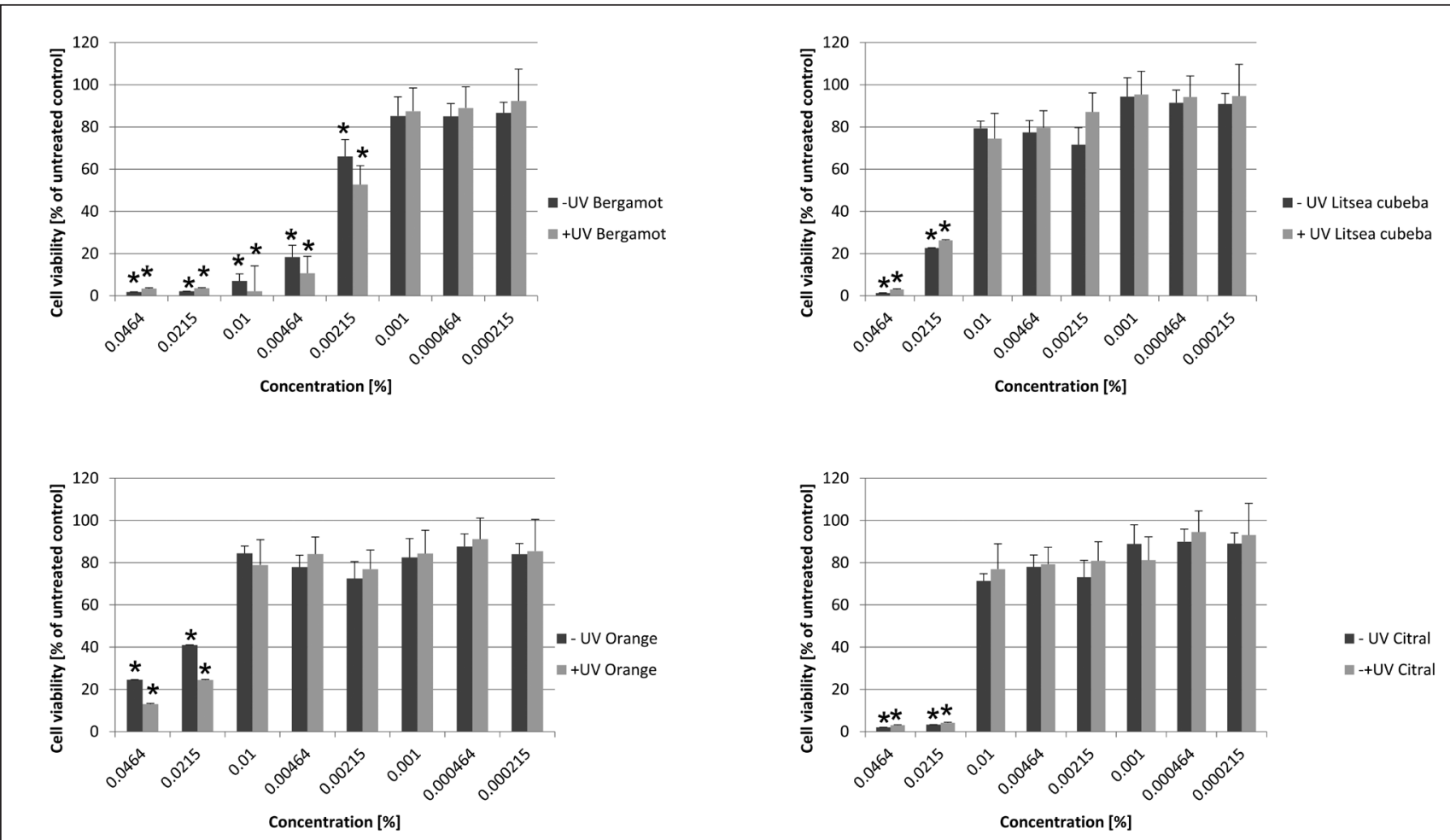

Fig. 1. The essential oils and citral phototoxicity. MTT cell viability assay of NIH 3T3 cells in the presence (+UV) and absence $(-U V)$ of UV light. Each value represents mean \pm SE from 3 different experiments. Significant difference $(p<0.05)$ between the test values and the control (cells treated without any tested substance) is marked by asterisk. 
Table 1. The essential oils and citral phototoxixity with PIF, MPE and EC50 values calculated from MTT cell viability assay

\begin{tabular}{|l|c|c|c|c|c|c|c|}
\hline Essential oil & Run & MPE & $\begin{array}{c}\text { Toxicity } \\
\text { probability }\end{array}$ & PIF & $\begin{array}{c}\text { Toxicity } \\
\text { probability }\end{array}$ & \multicolumn{2}{|c|}{ EC50 \% (v/v) } \\
\hline Bergamot & 1 & 0.139 & -1.000 & 2.694 & 0.960 & + UV & 0.0031 \\
\hline Bergamot & 2 & 0.276 & -1.000 & 4.557 & 1.000 & - UV & 0.0023 \\
\hline Litsea cubeba & 1 & 0.113 & -0.000 & 1.101 & 0.000 & - UV & 0.0110 \\
\hline Litsea cubeba & 2 & 0.077 & -0.000 & 1.466 & 0.000 & + UV & 0.0150 \\
\hline Orange & 1 & 0.100 & 0.501 & 5.435 & 0.954 & - UV & 0.0090 \\
\hline Orange & 2 & 0.193 & -1.000 & 8.231 & 1.000 & + UV & 0.0030 \\
\hline Citral & 1 & 0.100 & -0.000 & 0.712 & 0.000 & - UV & 0.0130 \\
\hline Citral & 2 & 0.002 & -0.000 & 0.951 & 0.000 & + UV & 0.0180 \\
\hline
\end{tabular}

half-maximal response) varied from $0.0023 \% \mathrm{v} / \mathrm{v}$ for bergamot to $0.018 \% \mathrm{v} / \mathrm{v}$ for citral (Table 1). Bergamot oil induced a probable phototoxic effect with PIF values 2.7 and 4.6, while only the orange oil was identified as clearly phototoxic (PIF value 5.4 and 8.2).

Based on the cytotoxicity/phototoxicity results, in the following in vitro methods employed in our study (ROS production measurement and comet assay) we selected three concentrations $0.0464,0.0215$ and $0.01 \% \mathrm{v} / \mathrm{v}$. The effect of the essential oils and citral samples in three selected concentrations on intracellular

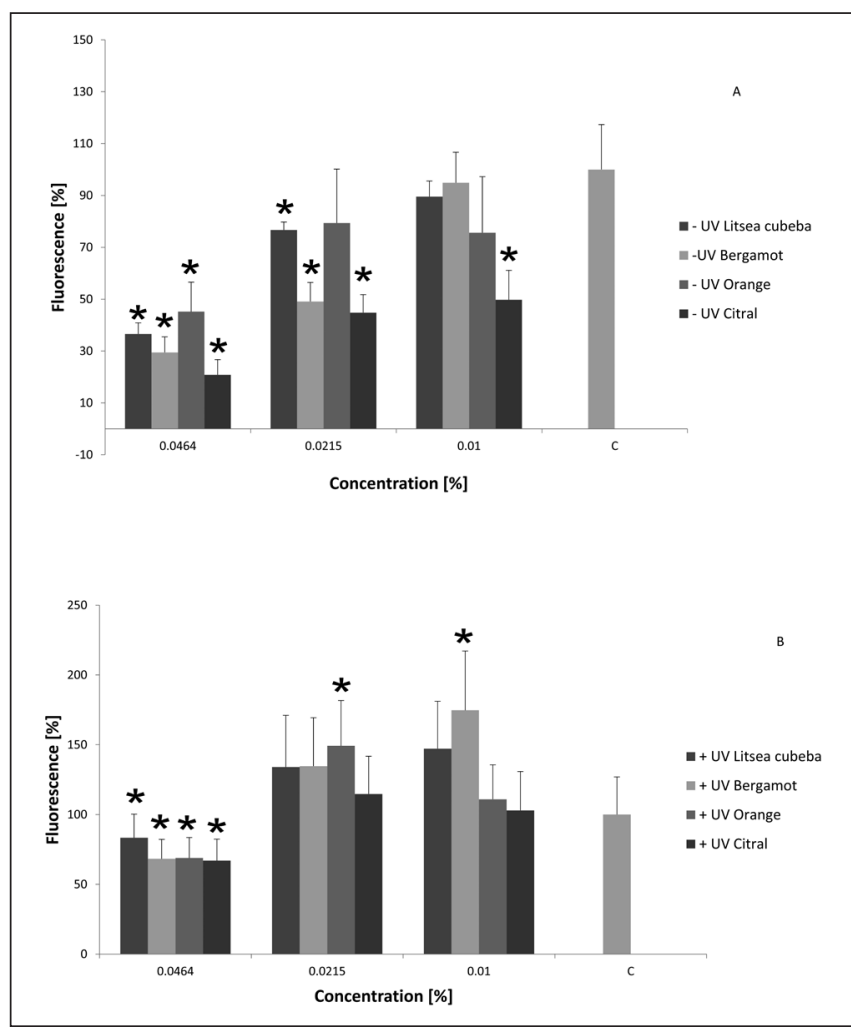

Fig. 2. Reactive oxygen species production light of three essential oils and citral measured without -UV light exposure (Fig. 2 A) and immediately after +UV light exposure (Fig. 2 B). The values represent percentage of measured fluorescence compared to the fluorescence of the control "C" (cells treated without any tested substance) representing 100\%. Each value represents mean \pm SE from 3 different experiments. Significant difference $(p<0.05)$ between the test values and the control "C" is marked by asterisk.
ROS formation in NIH 3 T3 cells was monitored with and without UV light irradiation with the radiation dose $5 \mathrm{~J} \mathrm{~cm}^{-2}$.

We measured the increase of ROS production immediately after completion of $1 \mathrm{~h}$ incubation and 50 minutes irradiation (+UV group) or dark incubation (-UV group) of cells with the tested substances. CM-H DCFDA, which was used as the fluorescence probe, can reveal the presence of $\cdot \mathrm{OH}$ (hydroxyl radical), $\mathrm{H}_{2} \mathrm{O}_{2}$ (hydrogen peroxide), $\mathrm{COO} \cdot$ (peroxyl radical), and $\mathrm{HOCl}$ (hypochlorous acid). A summary of the values for the essential oils and citral in three concentrations $(0.01-0.0215-0.0464 \% \mathrm{v} / \mathrm{v})$ are presented in Figure 2. The obtained data showed a difference in ROS production between the control cells and cells exposed to the essential oils and citral with (+UV) and without (-UV) ultraviolet light application. We observed a continuous decrease of fluorescence equalling to the lower ROS production in the $-\mathrm{UV}$ group cells with increasing concentrations of the tested samples. Citral showed the highest 5-fold decline when compared to the control cells. On the contrary, +UV group cells exhibited slight increase of ROS production in concentrations $0.0215 \% \mathrm{v} / \mathrm{v}$ and $0.01 \% \mathrm{v} / \mathrm{v}$. The highest percentage increase $(75 \%)$ was observed for bergamot and the concentration $0.01 \% \mathrm{v} / \mathrm{v}$.

The results of the comet assay which quantifies DNA damage are shown in Figure 3. Tail Length, Olive Tail Moment and Percentage of DNA in Tail are most commonly parameters used in comet assay evaluation. Tail Length can increase only while tails are being established, at relatively low damage levels. Subsequently, the tail increases in intensity but not in length as the dose of damage increases. For this reason, the percentage of DNA in the Tail is the most useful parameter, as it bears a linear relationship to break frequency, is relatively unaffected by threshold settings, and allows discrimination of damage over the widest possible range (in theory, from 0 to $100 \%$ DNA in tail) (17). The highest values of Tail Length after UV light irradiation were recorded for orange oil and citral. They reached up to $160 \mu \mathrm{m}$ for orange oil in concentration $0.0464 \%$ $\mathrm{v} / \mathrm{v}$ and $125 \mu \mathrm{m}$ for citral in the same concentration. The control cells showed almost no comet tail as their Tail Length was only 3 $\mu \mathrm{m}$. The cells incubated with the essential oils and citral without UV irradiation showed lower values of Tail Length suggesting lesser DNA damage. The highest value of Tail Length was observed again for orange oil in concentration $0.0464 \% \mathrm{v} / \mathrm{v}$ and it peaked at 120 $\mu \mathrm{m}$ (Fig. 3). The percentage of DNA in Tail expressed the amount of liberated DNA from the cell nucleus. The highest values for the cells irradiated by UV light were obtained for citral in concentrations of $0.0464 \% \mathrm{v} / \mathrm{v}$ and $0.0215 \% \mathrm{v} / \mathrm{v}$ where the values were 90 and 

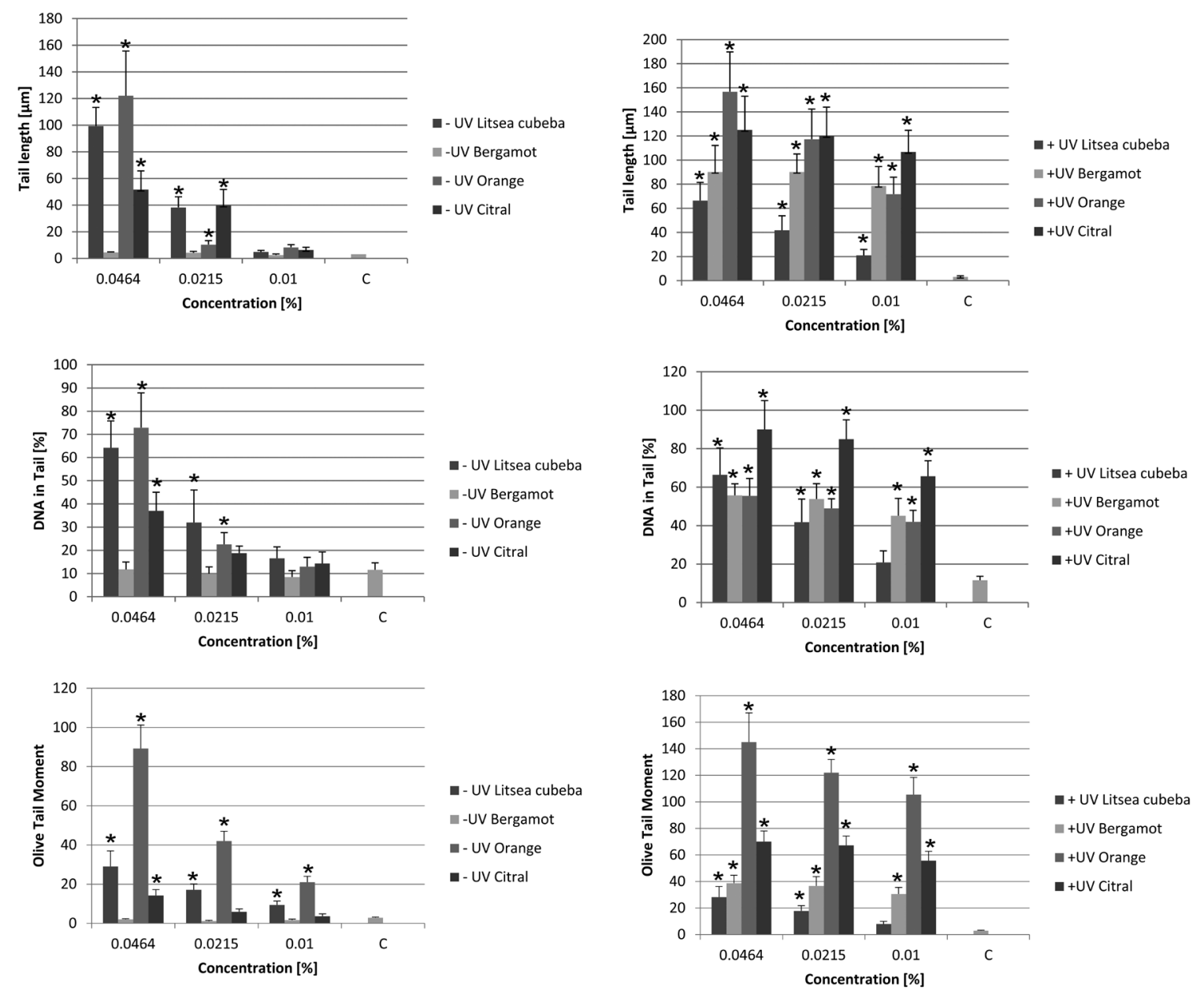

Fig. 3. Tail Length, Percentage of DNA in Tail, Olive Tail Moment in the cells with/without UV light exposure. Each value represents mean \pm SE from 3 different experiments. Significant difference $(p<0.05)$ between the test values and the control "C" (cells treated without any tested substance) is marked by asterisk.

$85 \%$, respectively. The DNA in cells not exposed to UV light was less fragmented, but a high amount (72\%) of DNA fragmentation was observed only for orange oil in concentration $0.0464 \% \mathrm{v} / \mathrm{v}$. Olive Tail Moment showed similar values as percentage of DNA in Tail. The cells exposed to orange oil with or without UV light exerted the highest values of Olive Tail Moment in concentration $0.0464 \% \mathrm{v} / \mathrm{v}$. The values in the cells treated with UV light were higher especially in concentrations $0.0215 \% \mathrm{v} / \mathrm{v}$ and $0.01 \% \mathrm{v} / \mathrm{v}$ compared to the non-irradiated cells.

\section{DISCUSSION}

The potential for phototoxic hazard is possible, and further research is required in order to assess substances which are intended to be used in consumer products and are expected to come into contact with skin exposed to sunlight. Essential oils are concentrated hydrophobic liquids containing volatile aroma and compounds extracted from plants. We selected Litsea cubeba oil, orange oil, bergamot oil and citral and employed MTT assay, comet assay and ROS production measurement to assess their phototoxic potential.

Mitochondrial membrane, cell aging or cell death can be changed by oxidative stress (19). ROS production and mitochon- drial dysfunction are therefore the possible contributing factors of essential oil toxicity. Stressed cells may produce ROS and particularly UV irradiation could have great influence on ROS production. Our results indicate that the examined essential oils decrease ROS production due to their antioxidant ability. Citral was proved to act as a general antioxidant inhibiting the generation of p-methylacetophenone (20). It was also shown that citral exhibits a good superoxide scavenging activity and that citral in a dose dependent manner inhibited the oxidative process involved in the formation of free radicals (21). Bergamot is also known as a source of natural antioxidants. Addition of bergamot oil to apricot and apple juices preserves their ascorbic acid content from thermal degradation and contributes to enhance the antioxidant activity, ensuring a product much richer in antioxidants and ascorbic acid (22). Antioxidant activity of Litsea cubeba oil was also proved by several studies $(23,24)$.

We can conclude that the cells incubated with all the essential oils and exposed to UV light exhibited rapidly decreased ROS production with the increased essential oil concentration when compared with the control cells. From all the tested essential oils citral exerted highest drop in ROS amount.

UV exposure may affect diverse biological functions including DNA replication, repair, cell cycle control, and chromatin remodelling (25). The breaks that occur as intermediates in nu- 
cleotide excision repair of UV-induced damage or bulky adducts are normally short-lived - at least in proliferating cells. To avoid any mechanisms involved in DNA reconstruction we performed the comet assay in 6 hours after UV irradiation. DNA repair mechanisms are involved immediately after UV exposure and complete DNA recovery takes about 2 hours to ensure that our results indicate irreversible DNA damage leading to cell death (26).

The tested substances are widely known as antioxidants which means that they inhibit the ROS production. The Reactive Oxygen Species, especially $* \mathrm{OH}$ radical can damage DNA by addition to the double bonds of DNA bases and abstraction of a hydrogen atom from the methyl group of thymine and/or the $\mathrm{C}-\mathrm{H}$ bonds of 2'-deoxyribose. On the contrary, flavonoids contained in the essential oils can protect human cells from hydrogen peroxide induced oxidative stress (27). However, there is evidence that furocoumarins may cause genotoxicity and phototoxicity (28, 29). It was also proved that d-limonene, a substance contained in bergamot, can initiate autophagic processes at concentration $0.02 \% \mathrm{v} / \mathrm{v}$. This concentration is responsible for initiation of multiple death pathways in human neuroblastoma cells, resulting in cytoskeletal alteration, caspase- 3 activation, DNA fragmentation, mitochondrial dysfunction, plasma membrane damage, and cleavage of pro-survival protein (30).

We observed the rapid increase of Tail Length, Percentage of DNA in Tail and Olive Tail Moment in the cells irradiated with UV light indicating DNA damage after UV exposure. We can conclude that all the tested substances are responsible for the DNA impairment. The cells irradiated with UV showed even higher DNA damage, except for one single concentration $(0.0464 \% \mathrm{v} / \mathrm{v})$ for orange oil showing lower percentage of DNA in tail when compared to the non-irradiated sample.

MTT assay was incorporated into the battery of tests to assess cell viability after their exposure to the essential oils. The cells exposed to UV light exhibited a decreased viability mainly in concentrations from $0.00215 \% \mathrm{v} / \mathrm{v}$ and higher. Bergamot oil showed the greatest decrease in viability out of the four tested essential oils. It diminished the cell viability after UV light exposure by around $50 \%$ in concentration $0.00215 \% \mathrm{v} / \mathrm{v}$. Our findings suggest that bergamot can be evaluated as probably phototoxic as its PIF values exceeded 2 and also MPE value was higher than 0.1 (Table 1). Orange can be labelled phototoxic as its PIF value was higher than 5 and MPE higher than 0.1. Litsea cubeba oil and citral cannot be classified as phototoxic according to their PIF and MPE values which were lower than 2 and 0.1 , respectively.

According to CosIng, the European Commission database with information on cosmetic substances and ingredients contained in the "Cosmetics Regulation" (EC) No 1223/2009 of the European Parliament and of the Council, none of the tested essential oils is regulated for use in finished products (31). Only the presence of citral must be indicated in the list of ingredients referred to in Article 19(1)g when its concentration exceeds: $0.001 \%$ in leaveon products and $0.01 \%$ in rinse-off products (31).

The International Fragrance Association (IFRA) has established in the 46th amendment of IFRA Standards restrictions for Bergamot oil expressed, limit in the finished skin contact product for leave on products is $0.4 \% \mathrm{v} / \mathrm{v}$, and for Bitter orange peel expressed, with a limit of $1.25 \%$ in leave on products (32).

For citrus oils and other furocoumarin containing essential oils IFRA has issued a standard set due to the phototoxic effects of the material. The limit only applies to applications on skin, excluding rinse-off products. If combinations of phototoxic fragrance ingredients are used, the use levels have to be reduced accordingly. The sum of the concentrations of all phototoxic ingredients, expressed in $\%$ of their recommended maximum level in the consumer product shall not exceed 100 (32).

In conclusion, four substances were tested for their phototoxic potential. Relatively low concentrations (less than $0.0464 \% \mathrm{v} / \mathrm{v}$ ) were tested and this proved that orange oil can be labelled as phototoxic and bergamot oil as probably phototoxic. The ROS measurements proved that essential oils used (bergamot, Litsea cubeba and orange oil) and citral possess strong antioxidative capacity. Our findings show that even low concentrations of the commercially used substances lead to diminished cell viability and DNA damage and especially the use of orange oil in consumer products should be reconsidered.

\section{Acknowledgement}

This work was supported by the Ministry of Education, Youth and Sports of the Czech Republic (MSMT-7778/2014) and (CZ.1.07/2.3.00/30.0004).

\section{Conflict of Interests}

None declared

\section{REFERENCES}

1. Tisserand R, Balacs T. Essential Oil Safety. A guide for health care professionals. Edinburgh (UK): Churchill Livingstone; 1995.

2. Luo M, Jiang LK, Zou GL. Acute and genetic toxicity of essential oil extracted from Litsea cubeba (Lour.) Pers. J Food Prot. 2005 Mar;68(3):581-8.

3. Bauer K, Garbe D, Surburg H. Common fragrence and flavor materials. 4th ed. Weinheim (Germany): Wiley; 2001

4. Verzera A, Trozzi A, Dugo G, Di Bella G, Cotroneo A. Biological lemon and sweet orange essential oil composition. Flavour Fragr J. 2004;19(6):544-8.

5. Flamm WG, Lehman-McKeeman LD. The human relevance of the renal tumor-inducing potential of d-limonene in male rats: implications for risk assessment. Regul Toxicol Pharmacol. 1991 Feb;13(1):70-86.

6. Lis-Balchin M. Aromatherapy science: a guide for healthcare professionals. London (UK): Pharmaceutical Press; 2006.

7. Sobolev AS, Jans DA, Rosenkranz AA. Targeted intracellular delivery of photosensitizers. Prog Biophys Mol Biol. 2000;73(1):51-90.

8. Placzek M, Frömel W, Eberlein B, Gilbertz KP, Przybilla B. Evaluation of phototoxic properties of fragrances. Acta Derm Venereol. 2007;87(4):312-6.

9. Lelièvre D, Justine P, Christiaens F, Bonaventure N, Coutet J, Marrot L, et al. The EpiSkin phototoxicity assay (EPA): development of an in vitro tiered strategy using 17 reference chemicals to predict phototoxic potency. Toxicol In Vitro. 2007 Sep;21(6):977-95.

10. Tice RR, Agurell E, Anderson D, Burlinson B, Hartmann A, Kobayash $\mathrm{H}$, et al. Single cell gel/comet assay: guidelines for in vitro and in vivo genetic toxicology testing. Environ Mol Mutagen. 2000;35(3):206-21.

11. Heaton PR, Ransley R, Charlton CJ, Mann SJ, Stevenson J, Smith BH, et al. Application of single-cell gel electrophoresis (comet) assay for assessing levels of DNA damage in canine and feline leukocytes. J Nutr. 2002 Jun;132(6 Suppl 2):1598S-603S.

12. Binder S, Kolarova H, Tomankova K, Bajgar R, Daskova A, Mosinger J. Phototoxic effect of TPPS4 and MgTPPS4 on DNA fragmentation of HeLa cells. Toxicol In Vitro. 2011 Sep;25(6):1169-72.

13. Tomankova K, Kejlova K, Binder S, Daskova A, Zapletalova J, Bendova $\mathrm{H}$, et al. In vitro cytotoxicity and phototoxicity study of cosmetics colorants. Toxicol In Vitro. 2011 Sep;25(6):1242-50.

14. Commission Directive 2000/33/EC of 25 April 2000 adapting to technical progress for the 27th time Council Directive 67/548 EEC on the approximation of laws, regulations and administrative provisions relating to the classification, packaging and labelling of dangerous substances. Off J Eur Communities. 2000 Jun 8;43(L136):90-107. 
15. Test no. 432: In Vitro 3 T3 NRU phototoxicity test. OECD Guidelines for the testing of chemicals, section 4 Health effects [Internet]. Paris: OECD; 2004 [cited 2016 Aug 28]. Available from: http://www.oecdilibrary.org/environment/test-no-432-in-vitro-3t3-nru-phototoxicitytest 9789264071162-en.

16. Holzhütter HG. A general measure of in vitro phototoxicity derived from pairs of dose response-curves and its use for predicting in vivo phototoxicity of chemicals. Altern Lab Anim. 1997;25:445-62.

17. Collins AR. The comet assay for DNA damage and repair: principles, applications, and limitations. Mol Biotechnol. 2004 Mar;26(3):249-61.

18. Fairbairn DW, Olive PL, O'Neill KL. The comet assay: a comprehensive review. Mutat Res. 1995 Feb;339(1):37-59.

19. Valdez LB, Zaobornyj T, Boveris A. Mitochondrial metabolic states and membrane potential modulate mtNOS activity. Biochim Biophys Acta. 2006 Mar;1757(3):166-72.

20. Liang CP, Wang M, Simon JE, Ho CT. Antioxidant activity of plant extracts on the inhibition of citral off-odor formation. Mol Nutr Food Res. 2004 Sep;48(4):308-17.

21. Rabbani SI, Devi K, Khanam S, Zahra N. Citral, a component of lemongrass oil inhibits the clastogenic effect of nickel chloride in mouse micronucleus test system. Pak J Pharm Sci. 2006 Apr;19(2):108-13.

22. Pernice R, Borriello G, Ferracane R, Borrelli RC, Cennamo F, Ritieni A. Bergamot: a source of natural antioxidants for functionalized fruit juices. Food Chem. 2009;112(3):545-50.

23. Hwang JK, Choi EM, Lee JH. Antioxidant activity of Litsea cubeba. Fitoterapia. 2005 Dec;76(7-8):684-6.

24. Saeio K, Chaiyana W, Okonogi S. Antityrosinase and antioxidant activities of essential oils of edible Thai plants. Drug Discov Ther. 2011 Jun;5(3):144-9.

25. dos Santos Montagner GF, Sagrillo M, Machado MM, Almeida RC, Mostardeiro CP, Duarte MM, et al. Toxicological effects of ultraviolet radiation on lymphocyte cells with different manganese superoxide dismutase Ala16Val polymorphism genotypes. Toxicol In Vitro. 2010 Aug;24(5):1410-6.

26. de With A, Leitz G, Greulich KO. UV-B-laser-induced DNA damage in lymphocytes observed by single-cell gel electrophoresis. J Photochem Photobiol B. 1994 Jun;24(1):47-53.

27. Ferlazzo N, Visalli G, Smeriglio A, Cirmi S, Lombardo GE, Campiglia $\mathrm{P}$, et al. Flavonoid fraction of orange and bergamot juices protect human lung epithelial cells from hydrogen peroxide-induced oxidative stress. Evid Based Complement Alternat Med. 2015;2015:957031. doi: 10.1155/2015/957031

28. Averbeck D, Averbeck S, Dubertret L, Young AR, Morlière P. Genotoxicity of bergapten and bergamot oil in Saccharomyces cerevisiae. J Photochem Photobiol B. 1990 Nov;7(2-4):209-29.

29. Chouchi D, Barth D, Reverchon E, Della Porta G. Supercritical CO2 desorption of bergamot peel oil. Ind Eng Chem Res. 1995;34(12):4508-13.

30. Berliocchi L, Ciociaro A, Russo R, Cassiano MG, Blandini F, Rotiroti $\mathrm{D}$, et al. Toxic profile of bergamot essential oil on survival and proliferation of SH-SY5Y neuroblastoma cells. Food Chem Toxicol. 2011 Nov;49(11):2780-92.

31. Regulation (EC) No $1223 / 2009$ of the European Parliament and of the Council of 30 November 2009 on cosmetic products. Off J Eur Union. 2009 Dec 22;52(L 342):59-209.

32. IFRA. Standards [Internet]. Geneva: IFRA [cited 2016 Aug 28]. Available from: http://www.ifraorg.org/.

Received March 22, 2015 Accepted in revised form August 23, 2016 